preliminary work, two lines of research were undertaken to investigate the differences in the bracken (Pteridium) population on the two sides of the island and the plants associated with the thrift (Armeria) in the gullies of the west coast.

\section{Royal Commission for the Exhibition of $|85|$ : Awards for 1953}

The Royal Commission for the Exhibition of 1851

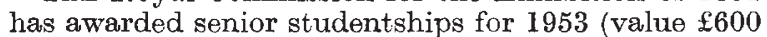
a year for two years) to the following for research as indicated : Miss M. P. V. Boarland (Bristol), organic chemistry at the Federal Technical College, Zurich; P. W. Higgs (London), theoretical physics at King's College, London; Dr. M. G. K. Menon (Bombay and Bristol), experimental physics at the University of Bristol ; and J. C. Ritchie (Aberdeen), botany at the University of Manitoba and the Botanical Gardens, Montreal. The Commission has also awarded the following overseas scholarships for 1953 (value $£ 450-500$ a year for two years): Canada: R. G. Ackman (Dalhousie), organic chemistry at the Imperial College of Science and Technology, London ; G. M. Graham (Dalhousie), physics at the University of Cambridge; and Miss M. M. Moodie (British Columbia), radiochemistry at the University of Cambridge. Australia: N. W. Tanner (Melbourne), physics at the University of Cambridge; and J. S. Turner (Sydney), physics at the Imperial College of Science and Technology, London. New Zealand : R. Hodges (New Zealand), organic chemistry at the University of Manchester. Republic of Ireland : Miss K. M. W. Gallagher (National University of Ireland), organic chemistry at the University of Bristol. Republic of India : S. Varadarajan (Delhi), organic chemistry at the University of Cambridge. Pakistan : F. H. Chowdhury (Dacca), chemistry at the University of Manchester.

\section{Leverhulme Research Awards for 1953}

THE following have been awarded Leverhulme research fellowships, tenable for periods up to two years, for research as indicated: Dr. (Miss) D. Atkins (research worker), comparative studies of ciliary feeding mechanisms of Brachiopods and their allies ; and Dr. E. R. Leach (reader in anthropology, University of London), study of traditional village organization among the Sinhalese of the Dry Zone of Ceylon. Leverhulme research grants have been awarded as follows: Dr. D. R. Arthur (lecturer in zoology, King's College, London), functional morphology of the genera Ixodes and Dermacentor in relation to their ecology; J. Bor (senior lecturer in physics, West Ham College of Technology), determination of the optical constants of metals and alloys ; E. J. H. Corner (lecturer in botany, University of Cambridge), revision of the genus Ficus for the Flora Malesiana Foundation; W. F. Grimes (director, London Museum), petrology of implements of the Neolithic and Bronze Ages in Great Britain; Dr. G. HeslopHarrison (lecturer in agricultural zoology, University of Durham), evolution and speciation of the Psyllidæ of Spain and Portugal; Dr. R. J. W. McLaughlin (demonstrator, University of Cambridge), differential thermal analysis of clay materials ; D. P. MacPherson (community centre warden, Lanarkshire), Gaelic folklore from Vatersay and Isle of Barra sources; Dr. T. B. Reynoldson (senior lecturer in zoology, University College, Bangor), the taxonomy and ecology of pond and lake planarians; and Dr. A. J. Ward (lecturer in mathematics, University of Cambridge), general topology.

\section{National Research Council of Canada : Scholarships} and Fellowships in Science and Engineering

THE National Research Council of Canada has granted 226 scholarships in science and engineering for 1953-54, totalling 224,000 dollars in value. These scholarships include 61 bursaries of 600 dollars each, 113 studentships worth 900 dollars, and 13 fellowships worth 1,200 dollars, nearly all of which are to be held in Canada. Special scholarships awarded for study outside Canada include seventeen awards of 1,500 dollars each, and seven awards worth 1,200 dollars each. These special scholarships are to be held in the following universities : eight at London, four at Cambridge, three at Oxford, two each at Birmingham and North Carolina, and one each at the Massachusetts Institute of Technology, and the universities of Chicago, Delaware, Pennsylvania and Wisconsin. One additional special scholarship worth 1,200 dollars has been awarded for study in Canada, at the University of Western Ontario. Fourteen overseas postdoctorate fellowships, each worth 2,500 dollars, have been granted for work at the following universities : three each at Oxford, Cambridge and London, and one each at the National Institute for Medical Research, and the universities of Birmingham, Leyden, Louvain and Uppsala.

Royal Meteorological Society : Officers for 1953-54

THE officers and council for 1953-54 of the Royal Meteorological Society are as follows: President, Prof. O. G. Sutton; Vice-Presidents, Prof. P. R. Crowe, Sir Charles Normand, Mr. C. D. Ovey and Prof. P. A. Sheppard; Vice-President for Canada, Mr. F. W. Benum; Vice-President for Scotland, Dr. A. E. M. Geddes ; Treasurer, Dr. J. S. Farquharson ; Secretaries, Dr. H. L. Penman, Dr. G. D. Robinson (Librarian), Mr. R. G. Veryard and Dr. T. W. Wormell (Editor) ; Council, Mr. G. A. Bull, Mr. H. Charnock, Instr. Cdr. C. R. Darlington, Mrs. A. C. Douglas, Dr. A. G. Forsdyke, Dr. R. Frith, Dr. G. L. Hogben, Mr. R. E. Lacy, Mr. F. H. Ludlam, Mr. N. Pye and Dr. R. S. Scorer.

\section{Sir Henry Wellcome Centenary Exhibition}

To mark the centenary of the birth of Sir Henry Wellcome on August 21, 1853, a commemorative exhibition will be opened at the Wellcome Foundation, Ltd., on Wednesday, July 8 , by Mr. Winthrop W. Aldrich, American Ambassador in London. This exhibition, which has been arranged and designed by the Wellcome Historical Medical Museum, will cover the whole period of Sir Henry's long life (18531936). The exhibits will range from interesting relics of his early days in the United States to sections on some of the world-famous research institutes which he established after he settled in Great Britain : the Wellcome Physiological Research Laboratories, Wellcome Chemical Research Laboratories, Wellcome Research Institution, Wellcome Museum of Medical Science, and Wellcome Historical Medical Museum and Library. It also deals with Wellcome's archæological expeditions to the-Sudan and Palestine.

\section{Symposium on Plasticity}

A symposium on plasticity, the fourth of its kind, will be held at Brown University, Providence, R.I., during September 1-3, under the auspices of the University, the Engineering Mechanics Division of 